\title{
PERSPEKTIF LAW AS AN ALLOCATIVE SYSTEM UNDANG-UNDANG OTORITAS JASA KEUANGAN
}

\author{
Agus Darmawan \\ Kementerian Keuangan Republik Indonesia \\ email : agus.gic@gmail.com
}

\begin{abstract}
Based on Friedman's point of view, search for secondary data in this research aims to provide an academic evaluation (assessment), the law as an allocative system against Law on Financial Services Authority. By using a normative approach, it can be concluded that the Law on Financial Services Authority academically has fulfilled the legal criteria for allocative system as intended by Friedman. Establishment of the Financial Services Authority (FSA) is intended as an independent agency that oversees the financial services sector of Indonesia, to strengthen accountability, transparency, and credibility of Bank Indonesia without diminishing the independence of state institutions, and policy making by the central bank will not be affected by the FSA, since the FSA served to increase oversight of financial institutions for the better.
\end{abstract}

Keywords: law, allocative system and financial services authority.

abstrak

Penelusuran terhadap data sekunder dalam penelitian ini bertujuan untuk memberikan evaluasi (penilaian) akademik berdasarkan sudut pandang Friedman, hukum sebagai sistem alokasi terhadap Undang-Undang Otoritas Jasa Keuangan (UU OJK). Menggunakan pendekatan normatif disimpulkan bahwa UU OJK secara akademik telah memenuhi kriteria hukum sebagai sistem alokasi yang dimaksud Friedman. Pembentukan OJK dimaksudkan sebagai lembaga independen yang mengawasi sektor jasa keuangan Indonesia, untuk memperkuat akuntabilitas, transparansi, dan kredibilitas Bank Indonesia tanpa mengurangi makna independensi lembaga negara tersebut, dan pengambilan kebijakan oleh BI tidak akan terpengaruh OJK, sebab OJK berperan meningkatkan pengawasan terhadap lembaga keuangan menjadi lebih baik.

Kata kunci : Hukum, Sistem Alokasidan Otorita Jasa Keuangan 


\section{A. Pendahuluan}

Lawrance M. Friedman dalam bukunya The Legal System: A Social Science Perspective, menyatakan bahwa output hukum adalah apa yang dihasilkan oleh hukum sebagai respon atas tuntutan sosial. Setiap hari ada jutaan tuntutan atas sistem hukum, juga ada jutaan respon. Bagaimanapun juga, kita bisa membicarakan tentang output dan respon sebagai hal-hal yang amat umum. Output-ouput umum ini adalah fungsi-fungsi menyeluruh dari hukum ${ }^{1}$.

Menurut Friedman, lingkup hukum terwujud dalam tiga bentuk yaitu: (1) Kelembagaan (institutions), (2) Norma (norms), dan (3) Fungsi (functions). Hal ini muncul karena masih belum adanya pengertian yang pasti tentang hukum dan masih beragamnya pengertian hukum dari para ahli hukum, bisa digolongkan ke dalam beberapa kelompok, mencerminkan perbedaan cara pandang terhadap hukum, dan perbedaan tujuan dalam penulisannya.

Berkenaan dengan lingkup Kelembagaan, di banyak masyarakat, ada orang-orang dan institusi yang menurut kelaziman merupakan bagian dari sistem hukum. Namun demikian, kita dapat membentuk sebuah definisi di seputar para profesional dan institusi, dan hasilnya sistem hukum di sini dibatasi oleh profesi yang relevan dari para pengacara, hakim, polisi, legislator, administrator, notaris, dan yang lainnya.

Berkenaan dengan Norma, hukum juga mencakup apa yang disebut dengan sekumpulan peraturan. Tentu saja dalam sebuah sistem hukum yang sakral, 'hukum' adalah kumpulan norma-norma sakral dan tidak lebih dari itu. Ahli hukum lainnya memandang hukum sebagai peraturan-peraturan atau norma-norma yang tidak selalu berarti bersifat resmi, mereka menekankan landasan adat kebiasaan dalam hukum, yakni pola-pola perilaku yang aktual. Michael Barkun menemukan adanya hukum dalam normanorma bersama suatu masyarakat yang memiliki aturan tentang hak dan kewajiban. Eugen Ehrlich membuat istilah 'hukum yang hidup' untuk menggambarkan pola-pola perilaku aktual dalam sebuah masyarakat. Bronislaw Malinowski mendapati bahwa hukum terdapat dalam pola-pola perilaku yang dijalankan dengan cara timbal balik. Dalam konteks Indonesia, hukum sebagai norma dapat dilihat dari ketentuan dalam berbagai peraturan perundang-undangan.

Berkenaan dengan Fungsi, sejalan dengan lingkup Norma, definisidefinisi hukum sedapat mungkin dihindari dari definisi yang terkait dengan pemerintah atau negara. Dalam hal ini, hukum didefinisikan sebagai definisi yang merumuskan hukum sesuai dengan fungsi-fungsi yang diperankannya.

\footnotetext{
${ }^{1}$ Lawrence M. Friedman, The Legal System: A Social Science Perspective, (New York: Russel Sage Foundation, 1975), hlm. 17.
} 
Salah satu fungsinya adalah penyelesaian sengketa. Kita juga bisa menamakan bahwa setiap aspek masyarakat dan setiap institusi yang menjalankan kontrol sosial adalah aspek yang bersifat legal. Definisi-definisi fungsional berguna dalam perbandingan kultur-kultur hukum. Institusiinstitusi yang namanya berbeda bisa menjalankan fungsi yang sama dan institusi atau peran yang sama bisa memiliki fungsi yang amat berbeda dalam masyarakat yang berbeda.

Sistem hukum bukanlah satu-satunya dalam hal ini, setiap sub sistem dalam masyarakat memiliki fungsi atau misinya sendiri. Pada taraf yang paling umum, sistem hukum memiliki fungsi untuk mendistribusikan dan menjaga alokasi nilai-nilai yang benar menurut masyarakat. Alokasi ini, yang tertanam dengan pemahaman akan kebenaran, adalah apa yang umumnya disebut sebagai keadilan. Aristoteles menarik garis perbedaan yang terkenal antara keadilan distributif dan keadilan komutatif, antara prinsip di mana kekayaan dan kehormatan dialokasikan di antara warga dan yang berkenaan dengan individu dan gugatan hukum. ${ }^{2}$ Di tengah konsep keadilan terdapat gagasan mengenai bagaimana mempertemukan orang dalam hal apa yang pantas mereka dapatkan, ditinjau secara etis tidak lebih, dan tidak kurang. Seperti apa hal ini dan bagaimana menjalankannya merupakan masalah yang telah digeluti oleh para filosof hukum selama berabad-abad. Di sini kita menghadapi gagasan tersebut hanya sebagai fakta sosiologis sebagai mandat yang diberikan oleh publik yang relevan dengan sistem hukum. Dengan kata lain, sistem hukum diandaikan untuk menjamin distribusi yang benar atau tepat (atau barangkali yang paling nyaman) di antara orang-orang dan kelompok. Dalam gugatan hukum dan transaksi individu, sistem harus menerapkan peraturan yang benar atau tepat (atau barangkali yang paling nyaman).

Fungsi lain dari sistem hukum yang tidak begitu bersifat global adalah sebagai penyelesaian sengketa. Konflik-konflik muncul dalam setiap masyarakat. Salah satu fungsi hukum yang pokok adalah menyediakan mesin dan tempat yang bisa dituju oleh orang untuk menyelesaikan konflik mereka dan merampungkan sengketa mereka. Tentu saja, fungsi ini tidak dimonopoli oleh sistem hukum, tetapi ada fungsi-fungsi lain yang ada di masyarakat.

Fungsi pokok lainnya dari sistem hukum adalah kontrol sosial, yang pada dasarnya berupa pemberlakuan peraturan mengenai perilaku yang benar. Para polisi dan hakim mengetahui bahwa pencuri harus ditangkap dan dikirimkan ke penjara. Kita bisa menamakan hukum pidana sebagai kontrol sosial primer. Sedangkan, kontrol sosial sekunder adalah menasehati, memberi pelajaran, dan merehabilitasi yang juga sama pentingnya. Pencuri

\footnotetext{
${ }^{2}$ Julius Stone, Human Law and Human Justice, (1965), hlm. 14.
} 
yang tertangkap dan diseret ke pengadilan tidak semata-mata dikontrol; ia juga "diberi pelajaran" (Apakah pelajaran itu akan berhasil atau tidak, adalah persoalan lain). Pengadilan-pengadilan di seluruh dunia bertindak atau mencoba bertindak sebagai guru moral, reformer, dan pelaku rehabilitasi.

Fungsi lain dari hukum adalah menciptakan norma-norma itu sendiri, bahan-bahan mentah bagi kontrol sosial. Kekuatan-kekuatan sosial melontarkan tekanan-tekanan; tuntutan-tuntutan ini "membentuk" hukum, namun institusi-institusi yang ada pada sistem hukum menuai tuntutantuntutan itu, membagi dan mengubahnya menjadi peraturan, prinsip, dan instruksi-instruksi bagi para pegawai negeri dan penduduk pada umumnya. Dalam menjalankan hal ini, sistem hukum bisa bertindak sebagai instrumen perubahan yang tertata, rekayasa sosial (social engineering).

Fungsi-fungsi yang disampaikan Friedman di atas terhitung sederhana dan nyata. Selain itu dimungkinkan bagi hukum, proses hukum, dan sistem hukum untuk menjalankan fungsi-fungsi instrumental lain yang tidak terlalu mencolok. Hukum mengekspresikan dan mendefinisikan norma-norma masyarakat. Ini tidak sama dengan mengajarkan dan mendakwahkan fungsi hukum, karena fungsi tersebut memiliki satu tujuan instrumental yaitu mengubah perilaku. Dengan kata lain, hukum mengumumkan seperti apa peraturan dan tolok ukurnya dan menegaskan bahwa masyarakat bisa dan akan menghukum para pelaku kejahatan yang bertindak melebihi batas. Tujuannya bukan untuk menekan demi mewujudkan tatanan, meskipun hal itu barangkali adalah tujuan tertinggi, melainkan menekan demi menghias norma-morma kesadaran masyarakat.

Secara umum hukum dalam arti fungsi (functions) berfungsi untuk mencapai keadilan (justice) baik keadilan dalam bentuk distributif (distributive justice) maupun keadilan komutatif (commutative justice). Lalu, hukum juga harus berfungsi sebagai alat atau sarana untuk menyelesaikan sengketa (settlement of dispute), dan berfungsi sebagai sarana kontrol sosial (social control).

Dari uraian di atas, secara sederhana dapat dipahami bahwa sebagai sebuah sistem, sistem hukum memiliki fungsi untuk mendistribusikan dan menjaga alokasi nilai-nilai yang benar menurut masyarakat. Alokasi ini, yang tertanam dengan pemahaman akan kebenaran, adalah apa yang umumnya disebut sebagai keadilan. Aristoteles menarik garis perbedaan yang terkenal antara keadilan distributif dan keadilan komutatif, antara prinsip di mana kekayaan dan kehormatan dialokasikan di antara warga dan yang berkenaan dengan individu dan gugatan hukum. Di tengah konsep keadilan terdapat gagasan mengenai bagaimana mempertemukan orang dan hal apa yang pantas mereka dapatkan, ditinjau dari etis, tidak lebih, dan tidak kurang. 
Dalam pengertian terluas, keadilan seperti apa yang hendak dihasilkan oleh sistem hukum? Konsep tersebut tentu saja tidak bisa didefinisikan dan selama ini menjadi menjadi subjek literatur filsafat yang luas. Masyarakat mengharapkan agar hukum memenuhi standar-standar etis mereka, dan masyarakat menilai berdasarkan bagaimana hukum itu memperlakukan orang-orang dan bagaimana hukum mendistribusikan untung dan rugi.

Dalam konteks hukum sebagai sistem alokasi yang disampaikan Friedman, kiranya hal ini juga perlu dilaksanakan di Indonesia, agar peraturan perundang-undangan yang dibuat tersebut sesuai dengan tujuannya. Salah satunya adalah dalam pembentukan Undang-Undang tentang Otoritas Jasa Keuangan, di mana undang-undang ini dibuat sebagai jawaban atas banyaknya permasalahan lintas sektoral di sektor jasa keuangan, yang meliputi tindakan moral hazard, belum optimalnya perlindungan konsumen jasa keuangan, dan terganggunya stabilitas sistem keuangan yang mendorong diperlukannya pembentukan Otoritas Jasa Keuangan (OJK) sebagai lembaga pengawasan keuangan yang terintegrasi. Namun, apakah pembentukan UU OJK ini dapat mencapai tujuannya, kiranya perlu suatu kajian: how it performs?; how it treats people?; how it distribute?; dan how its cost and benefit? atas undang-undang tersebut sebagaimana konsep Friedman mengenai hukum sebagai sistem alokasi.

Dari latar belakang sebagaimana telah diuraikan di atas, penulisan makalah ini akan meninjau efektifitas Undang-Undang Nomor 21 Tahun 2011 tentang Otoritas Jasa Keuangan yang diundangkan pada 22 November 2011 ditinjau dari konsep "Hukum sebagai Sistem Alokasi" yang disampaikan oleh Friedman.

Berdasarkan hal tersebut bagaimana efektifitas Undang-Undang Nomor 21 Tahun 2011 tentang Otoritas Jasa Keuangan ditinjau dari konsep Hukum sebagai Sistem Alokasi?

\section{B. Pembahasan}

\section{How it Performs?}

H.L.A. Hart berpendapat bahwa ciri khas dari suatu sistem hukum adalah kumpulan ganda dari peraturan-peraturan. Suatu sistem hukum adalah kesatuan dari 'peraturan-peraturan primer' dan 'peraturan-peraturan sekunder'. Peraturan primer adalah norma-norma perilaku, sedangkan peraturan sekunder adalah norma mengenai norma-norma ini, bagaimana memutuskan apakah semuanya itu valid, bagaimana memberlakukannya, dan lainnya. Tentu saja, baik peraturan primer maupun sekunder adalah samasama output dari sebuah sistem hukum. Semua itu adalah cara untuk menjelaskan perilaku sistem hukum bila dilihat secara menyilang. Para pihak yang berperkara akan berperilaku atas dasar substansi yang membuahkan perkiraan yang direspon mereka. Dalam konteks penyusunan UU OJK harus 
mencerminkan suatu output yang mampu mengatur pengawasan sektor jasa keuangan yang baik di Indonesia.

Secara historis, ide untuk membentuk lembaga khusus untuk melakukan pengawasan perbankan telah dimunculkan sejak diundangkannya Undang-Undang Nomor 23 Tahun 1999 tentang Bank Indonesia. Dalam undang-undang tersebut dijelaskan bahwa tugas pengawasan terhadap bank akan dilakukan oleh lembaga pengawasan sektor jasa keuangan yang independen dan dibentuk dengan undang-undang. Dengan melihat ketentuan tersebut, telah jelas tentang pembentukan lembaga pengawasan sektor jasa keuangan independen harus dibentuk. Bahkan, pada ketentuan selanjutnya dinyatakan bahwa pembentukan lembaga pengawasan akan dilaksanakan selambatnya 31 Desember 2002. Hal tersebut yang dijadikan landasan dasar bagi pembentukan suatu lembaga independen untuk mengawasi sektor jasa keuangan. Pembentukan UU OJK dimaksudkan untuk memisahkan fungsi pengawasan perbankan dari bank sentral ke sebuah badan atau lembaga yang independen di luar bank sentral.

Secara teoritis, terdapat dua aliran dalam hal pengawasan lembaga keuangan. Di satu pihak terdapat aliran yang mangatakan bahwa pengawasan industri keuangan sebaiknya dilakukan oleh satu institusi. Di pihak lain ada aliran yang berpendapat pengawasan industri keuangan lebih tepat apabila dilakukan oleh beberapa lembaga. Di Inggris misalnya, industri keuangannya diawasi oleh Financial Supervisory Authority (FSA), sedangkan di Amerika Serikat, industri keuangan diawasi oleh beberapa institusi. SEC misalnya, mengawasi perusahaan sekuritas, sedangkan industri perbankan oleh bank sentral (the Fed), FDIC, dan OCC. Alasan dasar yang melatarbelakangi kedua aliran ini adalah kesesuaian dengan sistem perbankan yang dianut oleh negara tersebut. Juga, seberapa dalam konvergensi di antara lembaga-lembaga keuangan. Dari sudut sistem, terdapat dua sistem perbankan yang berlaku, yaitu commercial banking system dan universal banking system. Commercial banking, seperti yang berlaku di Indonesia dan di Amerika Serikat, melarang bank melakukan kegiatan usaha non-bank seperti asuransi. Hal ini berbeda dengan universal banking, yang dianut oleh antara lain negara-negara Eropa dan Jepang, yang membolehkan bank melakukan kegiatan usaha keuangan non-bank seperti investment banking dan asuransi.

Secara empiris, survei yang dilakukan oleh Central Banking Publication (1999) menunjukkan bahwa dari 123 negara yang diteliti, tiga per empatnya memberikan pengawasan perbankan kepada bank sentral. Hal ini lebih menonjol di negara-negara sedang berkembang. Khusus untuk negara berkembang alasannya adalah sumber daya (resources). Bank sentral dianggap memadai dalam hal sumber daya (SDM dan dana). Dari kacamata politik, dicabutnya kewenangan pengawasan dari bank sentral sejalan 
dengan munculnya kecenderungan pemberian independensi kepada bank sentral. Ada kekhawatiran bahwa dengan independennya bank sentral, apabila bank sentral juga berwenang mengawasi bank, maka bank sentral akan memiliki kewenangan yang sedemikian besar. Bank of England misalnya, pada 1997 mendapatkan keindependenannya dan dua minggu kemudian kewenangan pengawasan bank diambil alih dari bank sentral. ${ }^{3}$

Apabila melihat sistem pengawasan perbankan yang dilakukan di beberapa negara yang disesuaikan dengan sistem perbankan, maka hal ini menunjukkan bahwa pengaturan pengawasan perbankan dimaksud melihat kondisi yang terjadi di masyarakat, dalam hal ini yang berkenaan dengan pengawasan perbankan. Sistem hukum yang sakral, "hukum" adalah kumpulan norma-norma sakral dan tidak lebih dari itu. Cendikiawan lainnya memandang hukum sebagai peraturan-peraturan atau norma-norma yang tidak selalu berarti bersifat resmi; mereka menekankan landasan adat kebiasaan dalam hukum, yakni pola-pola yang aktual. Michael Barkun menemukan adanya hukum dalam norma-norma yang tidak selalu berarti bersifat resmi; mereka menemukan landasan adat kebiasaan dalam hukum, yakni pola-pola perilaku yang aktual. Michael Barkun menemukan adanya hukum dalam norma-norma bersama suatu "masyarakat yang memiliki aturan tentang hak dan kewajiban". ${ }^{4}$ Eugen Ehrlich membuat istilah "hukum yang hidup" untuk menggambarkan pola-pola perilaku aktual dalam masyarakat. ${ }^{5}$ Bronislaw Molinowski mendapati bahwa hukum terdapat dalam perilaku-perilaku yang dijalankan dengan cara "timbal-balik". ${ }^{6}$

Latar belakang dibentuknya UU OJK adalah mewujudkan program pembangunan ekonomi nasional (yang di dalamnya termasuk sistem keuangan dan seluruh kegiatan jasa keuangan) yang dilaksanakan transparan dan akuntabel yang berpedoman pada prinsip demokrasi ekonomi sebagaimana diamanatkan Pancasila dan UUD 1945.

Terjadinya proses globalisasi dalam sistem keuangan dan pesatnya kemajuan di bidang teknologi informasi serta inovasi sosial telah menciptakan sistem keuangan yang sangat kompleks, dinamis, dan saling terkait antar sub sektor keuangan, baik dalam hal produk maupun kelembagaan. Di samping itu, adanya lembaga jasa keuangan yang memiliki hubungan kepemilikan di berbagai sub sektor keuangan (konglomerasi) telah

3 Zulkarnain Sitompul, Kemungkinan Penerapan Universal Banking System di Indonesia: Kajian dari Perspektif Bank Syariah, Jurnal Hukum Bisnis, Volume 20, AgustusSeptember, 2002, hlm. 1.

${ }^{4}$ Michael Barkun, Law Without Sanctions, (1968), hlm. 92.

5 Eugen Ehrlich, Fundamental Principles of the Sociology of Law, 1936. Leon Petrazycky membahas tentang hukum "intuitif", yakni perilaku hukum yang di dasarkan pada gagasan umum mengenai benar dan salah alih-alih pada perundangan atau peraturan khusus tertentu. Sebagian besar dari hukum intuitif walau tidak semuanya, bersifat tidak resmi.

${ }^{6}$ Bronislaw Molinowski, Crime and Custom in Savage Society, (1926). 
menambah kompleksitas transaksi dan interaksi antar lembaga jasa keuangan di dalam sistem keuangan.

Banyaknya permasalahan lintas sektoral di sektor jasa keuangan, yang meliputi tindakan moral hazard, belum optimalnya perlindungan konsumen jasa keuangan, dan terganggunya stabilitas sistem keuangan semakin mendorong diperlukannya pembentukan OJK sebagai lembaga pengawasan keuangan yang terintegrasi.

Penataan kembali struktur pengorganisasian dari lembaga-lembaga yang melaksanakan tugas pengaturan dan pengawasan di sektor jasa keuangan yang mencakup sektor perbankan, pasar modal, perasuransian, dana pensiun, lembaga pembiayaan, dan lembaga jasa keuangan lainnya dimaksud diharapkan mewujudkan koordinasi yang lebih efektif di dalam menangani permasalahan yang timbul di dalam sistem keuangan sehingga dapat lebih menjamin tercapainya stabilitas sistem keuangan.

Pembentukan OJK yang merupakan amanah dari UU Nomor 23 Tahun 1999 tentang Bank Indonesia sebagaimana telah beberapa kali diubah, terakhir dengan UU Nomor 6 Tahun 2009 tentang Penetapan Perpu Nomor 2 Tahun 2008 tentang Perubahan Kedua atas UU Nomor 23 Tahun 1999 tentang Bank Indonesia menjadi Undang-Undang, melakukan pengawasan sektor jasa keuangan yang mencakup perbankan, asuransi, dana pensiun, sekuritas, modal ventura dan perusahaan pembiayaan, serta badanbadan lain yang menyelenggarakan pengelolaan dana masyarakat, secara independen yang dalam pelaksanaan tugasnya berada di luar pemerintah. OJK berkewajiban menyampaikan laporan kepada Badan Pemeriksa Keuangan dan Dewan Perwakilan Rakyat.

Kewenangan OJK akan mengambil alih sebagian tugas dan wewenang Bank Indonesia, Badan Pengawas Pasar Modal dan Lembaga Keuangan (Bapepam-LK) dan institusi pemerintah lain yang selama ini mengawasi lembaga pengelola dana masyarakat.

Keberadaan OJK akan membantu Kementerian Keuangan dalam memfokuskan tugasnya pada fungsi fiskal, yaitu mengurus masalah penerimaan negara serta mengelola kekayaan negara dan piutang negara. Menurut Darmin Nasution, dalam sebuah diskusi di Kementerian Keuangan, disampaikan bahwa OJK itu independen walaupun independensinya tidak sampai seperti Bank Indonesia. Artinya, Pemerintah tidak intervensi terhadap OJK. Meski demikian, Presiden dapat mengambil kebijakan mengenai sektor keuangan dan memerintahkan OJK untuk melaksanakan keputusan kebijakan itu, dan harus disampaikan secara tertulis agar memiliki akuntabilitas yang jelas. 
Dalam menjalankan tugas pengaturan dan kewenangan, OJK mempunyai kewenangan ${ }^{7}$ :

a. membuat dan menetapkan peraturan sebagai pelaksanaan peraturan perundang-undangan di bidang jasa keuangan;

b. memberi dan mencabut izin untuk melakukan kegiatan di bidang jasa keuangan;

c. melakukan pengawasan terhadap pengelolaan dan kegiatan sektor jasa keuangan;

d. melakukan tindakan tertentu untuk mengurangi pelanggaran peraturan perundang-undangan di bidang jasa keuangan dan tindak kejahatan keuangan;

e. melakukan wewenang lain yang diamanatkan oleh peraturan perundangundangan di bidang jasa keuangan; dan

f. mengenakan sanksi atas pelanggaran terhadap peraturan perundangundangan di bidang jasa keuangan.

Sementara itu, wewenang OJK di bidang perbankan adalah wewenang pembuatan dan penetapan ketentuan yang bersifat microprudential, antara lain mencakup : ${ }^{8}$

a. untuk bidang kelembagaan bank, antara lain: mengenai perizinan untuk pendirian, pembukaan kantor, kepemilikan, dan kepengurusan, merger, konsolidasi dan akuisisi bank, pencabutan izin usaha, pembubaran dan likuidasi bank, termasuk pengaturan kelembagaan terhadap money changer;

b. untuk bidang kegiatan usaha bank, antara lain mengenai sumber dana, penyediaan dana, dan aktivitas bidang jasa;

c. untuk pengelolaan bank, antara lain mengenai likuiditas, rentabilitas, solvibilitas, laporan-laporan, permodalan bank dan kecukupan modal (Capital Adequacy Ratio), dan penunjukkan bank untuk melakukan kegiatan tertentu;

d. untuk pembinaan dan pengawasan bank, antara lain mengenai penilaian tingkat kesehatan bank dan tindak lanjut pembinaan dan pengawasan bank; dan

e. ketentuan microprudential lainnya, seperti pemeringkatan bank umum, pengaturan kualitas aset, cadangan piutang, penetapan batas maksimum pemberian kredit, sistem informasi debitur, restrukturisasi utang, kerahasiaan bank, penetapan pemenuhan persyaratan kelayakan dan kepatutan, dan lain-lain.

Kewenangan yang diberikan kepada OJK sebagaimana tersebut di atas, tetap dalam kerangka reponsibiltas dan akuntabilitas. Hal ini ditunjukan

\footnotetext{
${ }^{7}$ Penjelasan Pasal 52 ayat (1) Undang-Undang tentang Otoritas Jasa Keuangan.

${ }^{8}$ Penjelasan Pasal 52 ayat (2) Undang-Undang tentang Otoritas Jasa Keuangan.
} 
dengan OJK bertanggungjawab kepada presiden, untuk itu, OJK akan menyampaikan laporan secara periodik kepada presiden yang mencakup laporan kegiatan dan laporan keuangan. Presiden dapat meminta pihak independen untuk memeriksa OJK.

Untuk memberikan kesempatan kepada masyarakat, khususnya yang diwajibkan membayar register dan iuran-iuran, mengawasi penggunaan dana oleh OJK, lembaga ini harus mengumumkan laporan keuangannya kepada masyarakat. Untuk mendapatkan tanggapan dari industri jasa keuangan yang diawasinya, OJK menyelenggarakan pertemuan tahunan dengan para pelaku industri jasa keuangan.

Akuntabilitas OJK kepada publik juga diwujudkan dengan kehadiran OJK pada rapat-rapat kerja DPR. Dalam kesempatan tersebut, OJK memberikan penjelasan atau informasi mengenai kinerja pengawasannya.

Secara performa, UU OJK yang memberi kewenangan kepada OJK untuk melakukan pengawasan industri keuangan diharapkan merupakan bagian dari penyelenggaraan urusan kenegaraan yang terintegrasi secara baik dengan lembaga-lembaga negara lainnya di dalam mencapai tujuan dan citacita kemerdekaan Indonesia yang tercantum dalam konstitusi Republik Indonesia. OJK dalam pelaksanaan tugasnya memiliki independensi yang kuat karena secara kelembagaan OJK tidak berada di bawah otoritas lain di dalam sistem pemerintahan Negara RI dan secara orang perseorangan yang memimpin OJK harus memiliki kepastian atas jabatannya berupa jangka waktu jabatan yang tidak bisa diganti sejauh melaksanakan tugas dengan benar dan tidak terlibat dalam kriminalitas.

\section{How it Treats People?}

Struktur dan substansi adalah komponen riil dari sebuah sistem hukum, tetapi semua itu paling jauh hanya merupakan cetak biru atau rancangan, bukan sebuah mesin yang tengah bekerja. Persoalannya, pada struktur dan substansi tradisional semua itu bersifat statis, mereka seperti foto diam dari sebuah sistem hukum, bagai gambar tak bernyawa dan bias. Gambar itu tidak menampilkan gerak dan kenyataan. Sistem hukum yang digambarkan semata-mata sebagai struktur dan substansi formal adalah seperti ruang pengadilan yang diam karena tersihir, membeku, dan mandek di bawah pengaruh mantra keabadian yang ganjil.

Yang memberi nyawa dan realitas pada sistem hukum adalah dunia sosial eksternal. Sistem hukum tidak terisolasi atau terasing, melainkan ia bergantung secara mutlak pada input-input dari luar. Tanpa ada pihak-pihak yang berperkara, tidak akan ada pengadilan. Tanpa ada masalah dan kehendak untuk menyelesaikannya, tidak ada orang yang berperkara. Semua elemen sosial ini mencairkan kebekuan dan menggerakan sistem tersebut. 
Sebuah sistem hukum modern mengandung peraturan dalam jumlah yang amat banyak, sebagian objektif dan sebagian diskresioner. ${ }^{9}$ Proporsi antara satu tipe dengan tipe lainnya selalu berubah. Peraturan-peraturan diskresioner lebih menarik bagi para ahli hukum; peraturan-peraturan objektif nampak primitif atau formalistik. Tetapi pandangan sekilas pun terhadap buku-buku perundangan dari Negara manapun menunjukkan adanya ribuan peraturan objektif. Semua itu menjadi beban bagi hukum. Hukum modern menuntut adanya peraturan-peraturan yang seksama dan mendetail. Sistem hukum harus menjaga agar peraturan-peraturan diskresioner berada pada batas-batas yang pantas agar memberikan kepastian hukum. Demikian halnya dengan peraturan perundang-undangan di Indonesia, termasuk dalam Undang-Undang tentang Otoritas Jasa Keuangan harus memberikan kepastian hukum dan tidak diskriminasi dalam pengaturan dan pengawasan industri jasa keuangan.

Krisis yang terjadi di Asia pada tahun 1997-1998 sangat berpengaruh terhadap Indonesia, khususnya pada sektor perbankan. Krisis yang melanda Indonesia mengakibatkan banyak bank yang mengalami koleps sehingga banyak yang mempertanyakan pengawasan Bank Indonesia terhadap bank. Kelemahan kelembagaan dan pengaturan yang tidak mendukung diharapkan dapat diperbaiki (termasuk kemungkinan adanya diskriminasi dan tebang pilih dalam pengawasan lembaga jasa keuangan dalam peraturan sebelumnya) sehingga tercipta kerangka sistem keuangan yang lebih tangguh. Lembaga OJK akan mengambil alih kewenangan pengawasan perbankan yang selama ini dipegang oleh Bank Indonesia.

Untuk memberikan jaminan perlakuan hukum yang tidak diskriminatif dan tidak tebang pilih dalam pelaksanaan pengawasan sektor jasa keuangan, dalam penyusunan undang-undang OJK dilakukan identifikasi masalah, selanjutnya dikaji dan dianalisis kebaikan dan kelemahannya, serta menelaah praktek-praktek dalam membentuk suatu lembaga pengaturan dan pengawasan sektor jasa keuangan. Dalam hal ini perlu dipertimbangkan prinsip-prinsip untuk melakukan reformasi dan organisasi lembaga-lembaga yang melaksanakan fungsi pengaturan dan pengawasan sektor jasa keuangan, yaitu independensi, terintegrasi, dan menghindari benturan kepentingan.

Peran pengaturan dan pengawasan yang dilakukan oleh OJK diarahkan untuk mencapai efisiensi, persaingan yang sehat, perlindungan konsumen, serta memelihara mekanisme pasar yang sehat. Untuk itu, dalam UU Nomor 21 Tahun 2011 tentang Otoritas Jasa Keuangan, prinsip kesetaraan (level playing field), pengaturan dan pengawasan didasarkan pada

\footnotetext{
${ }^{9}$ Lawrence M. Freidman, Legal Rules and the Process of Social Change, (19 Stan. L. Rev, 1967), hlm. 786.
} 
prinsip-prinsip keadilan dan transparansi diterapkan sedemikian rupa untuk menciptakan aktifitas dan transaksi ekonomi yang teratur, efisien dan produktif, dan menjamin adanya perlindungan nasabah dan masyarakat. Hal ini merupakan wujud bahwa OJK tidak diskriminatif dan tidak tebang pilih dalam pelaksanaan pengawasan sektor industri jasa keuangan di Indonesia.

Semangat reformasi dan gejala transformasi sektor keuangan yang mengglobal yang ditandai oleh kemajuan teknologi informasi, inovasi produk-produk finansial yang makin kompleks dan keterkaitan entitas bisnis antar negara mendorong OJK mengambil bentuk dan struktur organisasi yang adaptif terhadap perkembangan zaman.

OJK menempatkan dirinya secara proporsional dan mengayomi berbagai kepentingan dari pelaku industri dan pemangku kepentingan lainnya. Apabila seluruh pemangku kepentingan (stakeholders) industri dapat menata seluruh pemangku kepentingan lainnya, OJK dapat menjadi fasilitator terhadap pasar. Fungsi surveillance dari OJK melalui sistem pengaturan dan pengawasan menjadi penting. Pemberian keleluasaan kepada industri untuk mengatur dirinya tetap ditempatkan dalam kerangka bahwa fungsi pengaturan dan pengawasan tetap merupakan tugas dan wewenang OJK dan senantiasa diarahkan untuk menjaga keberlangsungan sektor keuangan yang sehat dan stabil.

\section{How it Distribute?}

Joseph Gusfield menarik garis batas antara tujuan simbolis dan instrumental dari suatu peraturan atau hukum. ${ }^{10}$ Suatu hukum adalah instrumental jika ia tertuju pada perilaku konkret; hukum semacam ini memiliki "efek yang kecil" kecuali benar-benar diberlakukan. Hukum simbolis "tidak tergantung pada pemberlakuan untuk bisa menghasilkan efek". Mereka menjadi bermakna dengan "mensimboliskan penegasan publik mengenai cita-cita dan norma sosial di samping dengan kontrol sosial secara langsung". Dengan kata lain, hukum simbolis ditujukan kepada sikap sedangkan hukum instrumental pada perilaku.

Tujuan dan maksud pembuatan peraturan merupakan konsep yang sulit untuk dibahas. Tujuan adalah maksud dari para pembuat hukum, cukup sulit untuk mengetahui apa yang dikehendaki oleh pihak otoritas. Para pembuat hukum mungkin memiliki banyak maksud yang berlainan, mereka mengatakan sesuatu namun tujuannya bukan itu. ${ }^{11}$ Dalam UU OJK, yang dibuat dengan tujuan pengawasan industri jasa keuangan, maka dalam pelaksanaannya harus memegang teguh prinsip keadilan sesuai dengan hak

\footnotetext{
10 Joseph Gusfield, Moral Passage: The Symbolic Process in Public Designations of Deviance, (15 Social Problems, 1967), hlm. 175.

${ }^{11}$ Lawrence M. Friedman, Op.Cit. hlm. 56.
} 
dan kewajiban sebagaimana disampaikan dalam keadilan distributif menurut Aristoteles.

Aristoteles menarik garis perbedaan yang terkenal antara keadilan distributif dan keadilan komutatif, antara prinsip dimana kekayaan dan kehormatan dialokasikan diantara warga dan yang berkenaan dengan individu dan gugatan hukum. Di tengah konsep keadilan terdapat gagasan mengenai bagaimana mempertemukan orang dan hal apa yang pantas mereka dapatkan, ditinjau dari etis, tidak lebih, dan tidak kurang.

Untuk menjamin pelaksanaan tugas OJK sebagai otoritas pengaturan dan pengawasan terhadap industri sektor keuangan, maka dalam UU OJK ini diatur prinsip-prinsip pengaturan dan pengawasan yang bertujuan untuk memberikan keadilan bagi para seluruh stakeholder yang berkenaan dengan industri jasa keuangan.

Prinsip pertama adalah Independensi, di mana hal ini ditunjukkan bahwa OJK dalam melaksanakan tugas dan wewenangnya senantiasa independen dan bebas dari intervensi pihak-pihak berkepentingan, tentunya dalam koridor hukum yang juga menjamin bahwa independensi tersebut dapat dimintakan pertanggungjawabannya. Dalam tataran global, independensi dari lembaga pengatur dan pengawas sektor jasa keuangan telah menjadi prinsip utama yang dikemukakan oleh organisasi-organisasi internasional yang bertugas membuat standar internasional di masing-masing industri jasa keuangan. Dalam UU OJK ini juga mempertimbangkan dan melihat pengaturan dalam best practice yang ada antara lain: Basel Core Principles di bidang perbankan, IOSCO (International Organisation of Securities Commisions) untuk pasar modal, IAIS (International Association of Insurance Supervisors) untuk perasuransian, dan IOPS (International Organisation of Pension Supervisors) untuk dana pensiun.

Prinsip kedua, Terintegrasi. Dengan semakin pesatnya pertumbuhan dan kompleksitas kegiatan jasa keuangan sebagai akibat kemajuan luar biasa di bidang teknologi dan inovasi produk finansial yang canggih serta kecenderungan yang tidak bisa dihentikan dari entitas bisnis berbentuk konglomerasi dan adanya praktek-praktek arbitrase peraturan dari entitas bisnis jasa keuangan sehingga OJK melakukan suatu pengaturan dan pengawasan industri jasa keuangan secara terintegrasi.

Prinsip ketiga, Menghindari benturan kepentingan. Benturan kepentingan yang muncul dari adanya penggabungan fungsi yang berbeda di dalam satu lembaga merupakan suatu kenyataan dan pengalam yang terjadi di beberapa negara selama ini, misalnya pengaturan dan pengawasan perbankan dilaksanakan oleh bank sentral yang sekaligus bergerak sebagai otoritas moneter. Dalam kondisi ini, OJK diharapkan menjadi lembaga yang bisa menghindari adanya benturan kepentingan terkait dengan memisahkan 
fungsi pengawasan bank dari bank sentral yang fungsi utamanya sebagai otoritas moneter.

Dengan penerapan prinsip-prinsip sebagaimana disebutkan di atas, maka OJK diharapkan dapat melaksanakan fungsi pengaturan dan pengawasan jasa keuangan di Indonesia secara independen, adil, dan transparan sesuai dengan hak dan kewajiban atas seluruh stakeholder pengelolaan industri jasa keuangan. Dan keadilan distributif sebagaimana disampaikan Aristoteles dapat dirasakan juga dalam pelaksanaan pengawasan industri jasa keuangan di Indonesia.

\section{d. How its Cost and Benefit?}

Pandangan Roscou Pound tentang teori social interest yang merupakan embrio konsep "law as social engineering" yang disampaikan pada Konferensi "American Society of Sociology of Law" (1971) yang menyatakan "Looked at functionally, the law is an attempt to reconcile, to harmonise, to compromise these overlapping or complicating interest, ... so as to give effect to the greatest number of interests that weigh most in our civilization, with the least sacrifice of other interests..I venture to think of problems of eliminating friction and preculading wastein human enjoyment of the goods of existence, and of the legal order as system of social engineering whereby these ends are achieved". Pernyataan Pound ini menyatakan fungsi hukum sangat luas termasuk untuk rekonsiliasi, harmonisasi dan kompromi atas seluruh konflik kepentingan dalam masyarakat (individu, publik, dan negara), dengan prinsip hanya untuk kepentingan yang terbanyak dengan pengorbanan sekecil-kecilnya untuk kepentingan orang lain; itulah yang ia sebut law as social engineering atau $a$ system of social engineering. Berdasarkan pernyataan Pound tersebut semakin jelas bahwa, konsep hukum yang dimaksud olehnya, adalah konsep hukum masa depan yang memiliki visi yang jelas tentang bagaimana menyelesaikan berbagai konflik kepentingan dalam kehidupan masyarakat dan hubungannya dengan peranan negara dan individu. Pernyataan Pound ini ditafsirkan oleh Mochtar Kusumaatmadja dalam konteks pembangunan hukum nasional di Indonesia yang intinya bagaimana memerankan hukum sebagai sarana pembaruan masyarakat ${ }^{12}$.

Pendapat Pound kemudian mendorong perkembangan analisis nonhukum terhadap perkembangan hukum. Tokoh analisis ilmu ekonomi terhadap hukum adalah Richard Posner, yang menggunakan pendekatan ilmu ekonomi berbasis tiga prinsip yaitu nilai, kemanfaatan, dan efisiensi (value,

12 Romli Atmasasmita, Teori Hukum Integratif Rekonstruksi Terhadap Teori Hukum Pembangunan dan Teori Hukum Progresif, Cetakan kedua, (Yogyakarta: Genta Publishing, 2012), hlm 40. 
utility, and efficiency). Analisis ekonomi Posner kemudian dikembangkan oleh Robert Cooter dan Thomas Ullen, dengan prinsip maksimalisasi, keseimbangan, dan efisiensi (maximalization, equilibrium, and efficiency) terhadap hukum ${ }^{13}$.

Richard Posner menyatakan bahwa hukum yang efisien adalah pengalokasian tanggung jawab antara orang-orang yang terlibat dalam kegiatan berinteraksi sedemikian rupa untuk memaksimalkan nilai bersama, atau beberapa jumlahnya untuk hal yang sama, meminimalkan biaya kegiatan bersama. Penegakan hukum yang efisien berpihak kepada kualitas kontrol dari suatu proses (quality control assesment) dan bukan semata berpihak kepada efektivitas yang menitikberatkan kepada kuantitas sematamata. Targetisasi penegakan hukum hanya akan menciptakan bias dalam proses pembangunan bangsa bahkan cenderung kontraproduktif dan dapat menimbulkan kebohongan publik.

Pendekatan analisis ekonomi terhadap hukum (economic analisys of law approach) secara filosofis sejalan dengan pernyataan ahli hukum yang mengatakan bahwa 'hukum adalah untuk manusia, bukan sebaliknya'. Di sini kita harus memahami bahwa hukum sebagai alat (tool) untuk mencapai sesuatu, bukan sebagai tujuan yang sudah final. Analisis ekonomi terhadap hukum adalah suatu teori pilihan rasional di mana individu yang kritis dapat menentukan jalan yang terbaik untuk mencapai tujuannya serta manfaat dari tindakannya (action). Sebab, dalam pencapaian tujuannya, individu cenderung untuk memenuhi kepentingan pribadinya (self-interest), sehingga kadang berbenturan dengan kepentingan individu lain. Oleh karena itu, dibutuhkan hukum yang berkaitan dengan norma-norma untuk mengatur perilaku manusia. Jadi dapat disimpulkan bahwa teori pilihan rasional menjadikan analisis ekonomi terhadap hukum masuk kedalam bagian dari filsafat, khususnya filsafat hukum.

Analisis ekonomi terhadap hukum dalam mengukur efisiensi sebuah sistem hukum dalam hal ini menggunakan analisis ekonomi terhadap hukum bekerja dengan menggunakan metode ilmu ekonomi sebagai kerangka teoritis guna menganalisis aturan dan hukum yang digunakan pada kalangan masyarakat tertentu. Bahwa pemanfaatan metode ilmu ekonomi memungkinkan para penggagas analisis ekonomi terhadap hukum untuk menarik kesimpulan tentang keinginan manusia dan segala konsekuensi dari segi hukum dan bagaimana sebaiknya pengaturan hukumnya. Prediksi berbagai kemungkinan terhadap hukum, dilakukan terhadap pemberlakuan suatu aturan hukum, dilakukan lewat analisis terhadap berbagai model kurva yang bisa dilakukan dalam ilmu ekonomi dengan bantuan rumus-rumus eksakta yang presisi. Dengan demikian, pertanggungjawaban dari segi

${ }^{13}$ Ibid, hlm 42. 
ilmiah terhadap teori yang digunakan baik dari segi penerapan teori ekonomi maupun teori hukum lebih mudah dilakukan.

Teori analisis ekonomi terhadap hukum merupakan sambungan lidah dari utilitarianisme. Di mana manusia berupaya secara rasional untuk mencapai kepuasan maksimum bagi dirinya, namun kelemahan dari utilitarianisme adalah ketidakmampuannya menentukan apa keinginan seseorang dengan tepat. Sedangkan pemikiran analisis ekonomi terhadap hukum menemukan jawabannnya, yaitu keinginan seseorang terhadap sesuatu adalah ditentukan dengan melihat berapa besar kesediaannya untuk membayar apa yang dikendaki, yaitu agar keinginannya dapat terpuaskan. Ukurannya dapat dalam bentuk uang atau penggunaan sumber daya lain yang dimilikinya seperti kesediaannya untuk bekerja (labour). Singkatnya, analisis ekonomi terhadap hukum menyimpulkan segala sesuatu dapat direduksi dalam ungkapan singkat "berapa yang harus dibayar untuk memperoleh sesuatu agar tidak memperoleh sesuatu".

Analisis ekonomi terhadap hukum berdasarkan pada dua bidang akademis yaitu hukum dan ekonomi. Hukum dan ekonomi, oleh para akademisi hukum merupakan suatu frase yang dapat diartikan sebagai pengaplikasian hukum secara efisien dan rasional dengan menggunakan konsep-konsep maupun teori ilmu ekonomi. Kedua bidang tersebut saling berkaitan di mana ilmu ekonomi dapat menjadi salah satu alat ataupun perangkat dalam menganalisa kasus maupun permasalahan hukum. Atas dasar tersebut diharapkan muncul suatu solusi atau jawaban dari permasalahan hukum yang lebih efisien.

Analisis ekonomi terhadap hukum merupakan cabang dari ranah filsafat hukum. Lebih jelasnya, filsafat hukum membagi perhatiannya kedalam lima bagian yaitu law as reason, law as will, law as custom, laws and values, dan yang terakhir law as politics (Brown, Beverly, and Mac Cormick, 1998). Analisis ekonomi terhadap hukum masuk kedalam laws and values (hukum dan nilai). Analisis ekonomi terhadap hukum dapat dikatakan sebagai suatu teori kritis yang sifatnya normatif, karena berkaitan dengan teori pilihan rasional, di mana dalam prosesnya membutuhkan rasio dari individu tanpa memandang sebelah mata nilai-nilai yang ada dalam masyarakat.

Analisis ekonomi terhadap hukum memiliki beberapa pendekatan dalam pencapaiannya, salah satu inspirasinya adalah utilitarian. Hal ini diutarakan secara eksplisit oleh H.L.A. Hart, yang menjelaskan bahwa analisis ekonomi terhadap hukum terinspirasi dari utilitarianisme. ${ }^{14}$ Pendekatan utilitarianisme dari sisi filsafat tidak sepenuhnya mendasari

14 H.L.A Hart, Hart's Postscript, Essays on the Postcript to the Concept of Law, (Oxford,1983), hlm. 143. 
terbentuknya analisis ekonomi terhadap hukum, namun rasio atau felicific calculus yang digunakan Bentham dapat menjadi pintu bagi analisis ekonomi terhadap hukum untuk seterusnya berkembang dan disempurnakan oleh para filsuf maupun ekonom di masa mendatang.

Berkenaan dengan pembentukan UU OJK kiranya juga perlu memperhatikan pentingnya analisis non-hukum sebagaimana diuraikan oleh Posner, Cutter, dan Ullen. Kekhawatiran ini juga dirasakan Prof Romli Atmasasmita, yang menyatakan meragukan pembentuk undang-undang di Indonesia memperhatikan pentingnya analisis nonhukum karena hampir sebagian terbesar produk undang-undang di Indonesia memuat ketentuan sanksi pidana didalamnya yang sering kontra produktif dan tidak berhasil mencapai tujuan awal dari pembentukan undang-undang tersebut. ${ }^{15}$

Untuk menganalisis Cost and Benefits dari Undang-Undang OJK akan digunakan teori Economic Analysis of Law dari Posner. Richard Posner menggunakan pendekatan ilmu ekonomi berbasis tiga prinsip yaitu value, utility, and efficiency terhadap hukum ${ }^{16}$.

Secara value, pembentukan OJK adalah agar seluruh kegiatan di dalam sektor jasa keuangan dapat terselenggara secara teratur, adil, transparan, dan akuntabel, mampu mewujudkan sistem keuangan yang tumbuh secara berkelanjutan dan stabil, dan mampu melindungi kepentingan konsumen dan masyarakat, yang diwujudkan melalui adanya sistem pengaturan dan pengawasan yang terintegrasi terhadap keseluruhan kegiatan di dalam sektor jasa keuangan. Sehingga keberadaan OJK sebagai pengatur dan pengawas sektor jasa keuangan sangat diperlukan mengingat fungsi intermediasi yang diselenggarakan oleh berbagai jasa keuangan, dalam perkembangannya memberikan kontribusi yang cukup signifikan dalam penyediaan dana untuk pembiayaan ekonomi nasional.

Pembentukan OJK merupakan bentuk perhatian serius negara terhadap perkembangan kegiatan sektor jasa keuangan, dengan harapan akan terbentuk kerangka peraturan dan pengawasan sektor jasa keuangan yang terintegrasi dan komprehensip. Secara utility, OJK menyelenggarakan fungsi pemerintah dalam rangka mengatur dan mengawasi kegiatan sektor jasa keuangan, setiap pihak dilarang campur tangan dalam pelaksanaan tugas dan wewenang OJK. Artinya, untuk menjamin terselenggaranya pengaturan dan pengawasan sektor jasa keuangan yang optimal, OJK harus dapat bekerja secara independen dalam membuat dan menerapkan tugas dan wewenangnya sebagaimana dimaksud dalam peraturan perundang-undangan di bidang jasa keuangan.

\footnotetext{
${ }^{15}$ Op.Cit., hlm 42.

${ }^{16}$ Richard A Posner, Economic Analysis of Law, Edisi Keempat, (Little Brown and Company, 1992).
} 
Keberadaan OJK akan membantu Kementerian Keuangan dalam memfokuskan tugasnya pada fungsi fiskal, yaitu mengurus masalah penerimaan dan pengeluaran negara serta mengelola kekayaan negara dan piutang negara. Menurut Darmin Nasution, OJK itu independen walaupun independensinya tidak sampai seperti Bank Indonesia. Artinya, pemerintah tidak intervensi terhadap OJK. Meski demikian, Presiden dapat mengambil kebijakan mengenai sektor keuangan dan memerintahkan OJK untuk melaksanakan keputusan kebijakan itu, dan harus disampaikan secara tertulis agar memiliki akuntabilitas yang jelas.

Kedudukan OJK bersifat independen dalam menjalankan tugasnya dan kedudukannya berada di luar pemerintah dan berkewajiban menyampaikan laporan kepada BPK dan DPR. Namun demikian, OJK bertanggungjawab kepada Presiden. Dalam pelaksanaan tugas dan kewenangannya, OJK perlu melakukan koordinasi dengan beberapa lembaga seperti Bank Indonesia, Lembaga Penjaminan Simpanan (LPS) serta Menteri Keuangan bahkan Presiden agar dapat secara efektif dan efisien dalam memecahkan permasalahan di sektor keuangan.

Secara efficiency, pembentukan OJK didorong oleh perkembangan perekonomian global yang mendorong peningkatan fungsi perbankan. Sebagai lembaga keuangan, perbankan memegang peranan yang sangat penting dalam suatu sistem keuangan negara. Bank merupakan badan usaha yang berfungsi untuk menghimpun dana dari masyarakat, baik dalam bentuk simpanan maupun menyalurkan kredit kepada masyarakat. Melalui fungsi perbankan ini diharapkan dapat meningkatkan pemerataan, pertumbuhan ekonomi, dan stabilitas nasional ke arah peningkatan kesejahteraan rakyat banyak.

Hal tersebut sesuai dengan apa yang telah diamanatkan dalam pembukaan UUD 1945 alinea keempat sebagai tujuan Negara Indonesia. Berdasarkan tujuan Negara tersebut diselenggarakan pembangunan Negara Indonesia. Namun, pada implementasinya telah terjadi penyimpangan, khususnya di bidang perbankan, antara lain ketidakhati-hatian dunia perbankan dalam mengelola dana dari masyarakat. Kondisi ini diperparah dengan kurang memadainya perangkat hukum yang dapat memayungi terbentuknya sistem keuangan nasional yang baik. Penyimpangan ini telah mengakibatkan distorsi praktek ekonomi pasar yang mengakibatkan fondasi perekonomian nasional menjadi lemah.

Seharusnya perekonomian nasional dapat mampu tumbuh dengan stabil dan berkelanjutan, menciptakan kesempatan kerja yang luas dan seimbang di semua sektor perekonomian, dan memberikan kesejahteraan secara adil kepada seluruh rakyat Indonesia sehingga penyimpangan tersebut harus cepat diperbaiki. Untuk itu, dalam melakukan tugasnya ini, bank 
sebagai lembaga yang menghimpun dana dari masyarakat perlu mendapatkan pengawasan yang efektif.

Pada mulanya Bank Indonesia merupakan lembaga negara yang independen dalam melaksanakan tugas dan wewenangnya. Bank Indonesia dalam menjalankan tugas pengawasan terhadap bank sering mengalami kesalahan. Hal ini dapat dilihat dari banyaknya kasus yang akhirnya merugikan masyarakat dan hilangnya kepercayaan masyarakat terhadap bank, misalnya kasus BLBI (Bantuan Likuiditas Bank Indonesia), Skandal Bank Bali, dan Skandal Bank Century.

Untuk mengatasi berbagai tantangan di atas, perlu dilakukan penyesuaian mekanisme perumusan kebijakan moneter dan penataan kembali kelembagaan. Pembentukan OJK sangat diperlukan keberadaannya sebagai lembaga yang independen dalam mengawasi sektor jasa keuangan Indonesia. Langkah tersebut diperlukan untuk memperkuat akuntabilitas, transparansi, dan kredibilitas Bank Indonesia tanpa mengurangi makna independensi lembaga negara tersebut.

Terkait dengan regulasi, tampak erat antara OJK dan Bank Indonesia sebagai otoritas moneter sekaligus bank sentral. Dengan demikian apabila kita perhatikan pasal demi pasal dalam UU OJK telah memperhatikan sepenuhnya pasal demi pasal dalam UU Bank Indonesia. Tujuannya adalah tercapainya efisiensi pembentukan OJK, yaitu terdapatnya pembagian bidang tugas secara jelas dan rinci antara OJK dan Bank Indonesia sehingga dapat lebih koordinatif dan komunikatif dalam eksekusinya, khususnya dalam arus informasi. Dengan adanya pembagian tugas, akuntabilitas, dan responsibiltas kedua lembaga yang membawahi sistem keuangan dan moneter di Indonesia dapat diukur.

Pembentukan otoritas jasa keuangan di beberapa negara di dunia belum menunjukkan peran dan menunjukkan hasil yang signifikan. Efektifitas OJK masih dipertanyakan di seluruh dunia, bahkan Inggris yang menjadi pionir OJK juga mengalami kegagalan dan justru saat ini memunculkan wacana yang sangat gencar di negara tersebut untuk kembali ke sistem lama. Hal ini dipicu oleh kegagalan OJK Inggris mencegah krisiskrisis bank seperti dalam kasus Northern Rock.

Hal lain juga terjadi di Australia, di mana hal ini dipicu oleh suatu kondisi di mana bank sentral, The Reserve Bank of Australia(RBA) dengan The Australian Prudential Regulation Authority (APRA). Tugas APRA tidak hanya mengawasi industri perbankan, tetapi juga seluruh deposit taking company, termasuk asuransi, superannuation funds, credit unions, building society, dan friendly society. Sementara itu, RBA tetap bertanggungjawab sebagai pengendali moneter, termasuk sistem pembayaran. Kondisi ini dirasakan tidak efektif. 
Kegagalan beberapa lembaga OJK di negara-negara lain, seharusnya menjadi pelajaran berharga bagi pendirian OJK di Indonesia. Pendirian OJK di Indonesia sangat diperlukan untuk menjaga independensi dan menghindari pelaksanaan pengawasan dalam industri keuangan di Indonesia. Hal terpenting lainnya adalah bahwa jangan sampai pembentukan OJK hanya sekedar untuk memenuhi tuntutan zaman, mengikuti perkembangan yang terjadi secara cepat pada sektor jasa keuangan, terutama dengan munculnya konglomerasi di sektor itu. Untuk itu OJK harus memberikan jaminan kepada Bank Indonesia, khususnya dalam mengakses informasi terkait pengawasan microprudential perbankan.

\section{Penutup}

Dari uraian di atas, maka berkenaan dengan pembentukan UndangUndang Nomor 21 Tahun 2011 tentang Otoritas Jasa Keuangan dapat disimpulkan beberapa hal, yaitu:

1. Undang-UndangNomor 21 Tahun 2011 tentang Otoritas Jasa Keuangan ditinjau dari konsep "Hukum sebagai Sistem Alokasi" yang disampaikan oleh Friedman dengan beberapa kajian terkait how it performs?; how it treats people?; how it distribute?; dan how its cost and benefit? telah memenuhi kajian sebagaimana disampaikan Friedman dimaksud. Keberadaan OJK sebagai lembaga yang dilahirkan dari UU ini sangat diperlukan untuk memperbaiki mekanisme perumusan kebijakan moneter dan penataan kembali kelembagaan dalam sektor keuangan dan perbankan;

2. pembentukan lembaga OJK sebagai amanah dari UU Nomor 21 Tahun 2011 sangat diperlukan keberadaannya sebagai lembaga independen yang mengawasi sektor jasa keuangan Indonesia. Langkah tersebut diperlukan untuk memperkuat akuntabilitas, transparansi, dan kredibilitas Bank Indonesia tanpa mengurangi makna independensi lembaga negara tersebut; dan

3. keberadaan OJK tidak akan mengganggu Bank Indonesia dalam mengambil kebijakan di bidang moneter karena segala informasi yang dibutuhkan terjamin ketersediaannya. Terbentuknya OJK diharapkan pengawasan di sektor jasa keuangan menjadi lebih baik dibandingkan sebelum adanya OJK. 


\section{Daftar Pustaka}

\section{A. Buku}

Atmasasmita, Romli, 2012. Teori Hukum Integratif Rekonstruksi Terhadap Teori Hukum Pembangunan dan Teori Hukum Progresif, Cetakan kedua, Yogyakarta: Genta Publishing.

Barkun, Michael, 1968. Law Without Sanctions.

Ehrlich, Eugen, 1936. Fundamental Principles of the Sociology of Law.

Friedman, Lawrence M., 1975, The Legal System: A Social Science Perspective, New York: Russel Sage Foundation. Change, 19 Stan. L.Rev. 1967, Legal Rules and the Process of Social

Gusfield, Joseph R., 1967. Moral Passage: The Symbolic Process in Public Designations of Deviance, 15 Social Problems.

Hart, H.L.A., 1983. Hart's Postscript, Essays on the Postcript to the Concept of Law, Oxford.

Molinowski, Bronislaw, 1926, Crime and Custom in Savage Society.

Posner, Richard A., 1992. Economic Analysis of Law, Edisi Keempat, Little Brown and Company.

Sitompul, Zulkarnain, Kemungkinan Penerapan Universal Banking System di Indonesia: Kajian dari Perspektif Bank Syariah, Jurnal Hukum Bisnis, Volume 20, Agustus-September, 2002.

Stone, Julius, 1965. Human Law and Human Justice.

\section{B. Peraturan Perundang-undangan}

Undang-Undang Nomor 23 Tahun 1999 tentang Bank Indonesia sebagaimana telah beberapa kali diubah, terakhir dengan UndangUndang Nomor 6 Tahun 2009 tentang Penetapan Peraturan Pengganti Undang-Undang Nomor 2 Tahun 2008 tentang Perubahan Kedua atas Undang-Undang Nomor 23 Tahun 1999 tentang Bank Indonesia menjadi Undang-Undang.

Undang-Undang Nomor 21 Tahun 2011 tentang Otoritas Jasa Keuangan. 